\title{
Electrophorethic Analysis of Esterases and Other Soluble Proteins from Representatives of Phytopathogenic Bacterial Genera
}

\author{
By T. A. EL-SHARKAWY* AND D. HUISINGH \\ Department of Plant Pathology, North Carolina State University, \\ Raleigh, North Carolina 27607, U.S.A.
}

(Accepted for publication 9 July 197I)

SUMMARY

Electrophoretic patterns of esterases and other soluble proteins from two isolates of Agrobacterium rhizogenes, three of A. tumefaciens, two of Corynebacterium faciens, eight of $C$. michiganense, three of Pseudomonas phaseolicola, two of Erwinia carotovora, and four of Xanthomonas fragariae were determined. Similar protein patterns were obtained for isolates representing a given bacterial species, with the exception of one isolate of $A$. tumefaciens which differed markedly from the other two isolates tested. All isolates possessed active esterases. None of the Corynebacterium isolates tested showed activity bands for dehydrogenases. Results demonstrated the applicability of the technique in differentiating between phytobacterial genera and between species of a given genus.

\section{INTRODUCTION}

A current classification of bacteria (Breed, Murray \& Smith 1957) is based on morphological and biochemical properties. Phytopathogenic bacteria are also placed in different genera on the basis of these criteria. Disc electrophoresis of soluble proteins and enzyme has been applied to the differentiation and taxonomy of micro-organisms. Electrophoretic protein patterns were found useful with fungi (Chang, Srb \& Steward, I962; Clare, I963; Clare \& Zentmyer, I966; Durbin, I966; Gill \& Powell, I967; Stipes, 1967; Clare, Flentje \& Atkinson, 1968; Hall, Zentmyer \& Erwin, 1969), actinomycetes (Gottlieb \& Hepden, 1966), pleuro-pneumonia-like organisms (Fowler, Coble, Crammer \& Brown, 1963), and mycoplasma (Razin \& Rottem, 1967; Rottem \& Razin, 1967; Razin, 1968). Esterase and other enzymes have also been found to be useful taxonomic criteria for bacteria (Norris, I964; Conn \& Willox, 1965; Lund, I965; Robinson, I966; Morichi, Sharpe \& Reiter, I968).

It was therefore thought to be of interest to apply the electrophoretic method to phytopathogenic bacteria which to date have received relatively little attention (Huisingh \& Durbin 1965, I967; El-Sharkawy \& Huisingh, I968; Gill \& Khare, I968; Smith \& Powell, I968). In experiments reported here, the soluble protein and esterase electrophoretic patterns of some representatives of five phytobacterial genera are examined.

* Present address: Department of Plant Pathology, Cotton Diseases Research Division, Ministry of Agriculture, Orman, Giza, Egypt. 


\section{METHODS}

Organisms. The following isolates of phytopathogenic bacteria were used: Agrobacterium rhizogenes A-3, A-4; A. tumefaciens A-IO, A-I2, A-I3; Corynebacterium faciens $\mathrm{CF}-2$, I2974; C. michiganense mut. A, mut. B, $10202 \mathrm{~A}, 10202 \mathrm{~B}, 829 \mathrm{~A}, 829 \mathrm{AL}, 100-\mathrm{B}, 7-\mathrm{A}$; Erwinia carotovora KL-3I, $7 \mathrm{KL}-46$; Pseudomonas phaseolicola PP, HB-33, HB 40; Xanthomonas fragariae 7 XFIO, XFI8, XF26, XF32. Isolates of $E$. carotovora, $P$. phaseolicola and $X$. fragariae were provided by D. C. Hildebrand, Department of Plant Pathology, University of California, Berkeley; the remaining isolates were obtained from a collection maintained at the Department of Plant Pathology, North Carolina State University, Raleigh.

Culture procedures and preparation of cell-free extracts. All bacterial isolates were grown in nutrient-glucose broth (8.0 g. Difco nutrient broth, $5^{\circ} \mathrm{g}$ g. glucose $\left./ 1\right)$. Inoculated flasks were incubated on a rotary shaker run at $200 \mathrm{rev} . / \mathrm{min}$. at $27^{\circ}$ to $28^{\circ}$ for 48 to $60 \mathrm{~h}$. Bacteria were harvested by centrifugation at $12,000 \mathrm{~g}$ at $0^{\circ}$ in a Sorvall $\mathrm{RC}-2$ centrifuge (SS-34 rotor). The pellets were washed twice by centrifugation in $0.05 \mathrm{M}$-tris- $\mathrm{HCl}$ buffer, $\mathrm{pH} 7 \cdot 8$. Bacterial cells were disrupted by sonication for $3 \mathrm{~min}$. at $0^{\circ}$, in a $0.05 \mathrm{M}$-tris- $\mathrm{HCl}$ buffer, $\mathrm{pH} 7.8$, containing $0.57 \mathrm{~mm}$-ascorbic acid, $0.64 \mathrm{~mm}$-cysteine hydrochloride, and $0.4 \mathrm{M}$-sucrose using a Bronson model S-75 Sonicator. The homogenates were then centrifuged at 48,000 $\mathrm{g}$ for $60 \mathrm{~min}$. and the clear supernatant extracts were stored at $-20^{\circ}$ until they were used. Protein concentration in the extracts was determined by the method of Lowry et al. (195I).

Gel electrophoresis, protein staining and esterase localization. Polyacrylamide gels $(7 \%)$ were prepared according to the procedure of Davis (1964) and $5 \mathrm{~mm}$-tris-48 $\mathrm{mm}$ glycine buffer, $\mathrm{pH} 8 \cdot 3$, was used in electrophoresis. The bacterial extracts in I M-sucrose were placed on top of the stacking gels $(2.5 \%)$ rather than in sample gels. The amount of extracts was adjusted to contain $200 \mu \mathrm{g}$. protein/gel. Electrophoretic separation was performed at $0^{\circ}$ with a Beckman Constat power supply. Current at $3 \mathrm{~mA} /$ gel was applied until the dye marker band (bromophenol blue) reached the interface between the stacking and the separation gels, then raised to $5 \mathrm{~mA} / \mathrm{gel}$. The electrophoretic separation continued until the dye marker bank migrated about 35 to $40 \mathrm{~mm}$. into the separation gel. Gels were removed from the glass tubes and stained either for soluble protein with I $\%(\mathrm{w} / \mathrm{v})$ Amido black in $7 \%(\mathrm{v} / \mathrm{v})$ acetic acid or for locating esterase activity by incubating gels in $0.1 \mathrm{M}$-phosphate buffer, $\mathrm{pH} 7.0$, for Io min. and then transferring them to a reaction mixture containing $0.03 \mathrm{~g}$. Fast blue RR salt (stabilized diazonium salt) as the coupler, $0.5 \mathrm{ml}$. of I $\%(\mathrm{w} / \mathrm{v}) \alpha$-naphthyl acetate in $50 \%$ $(\mathrm{v} / \mathrm{v})$ acetone as the substrate, and $24.5 \mathrm{ml}$. distilled water. They were incubated at room temperature in the dark for periods of 5 to $30 \mathrm{~min}$. depending on the enzymic activity. Controls were run in the above reaction mixture by replacing the substrate solution with $0.5 \mathrm{ml}$. of $50 \%$ acetone. Enzymic reaction was halted by immersing the gels in $7 \%$ acetic acid. Gels stained for soluble proteins were electrophoretically destained in $7 \%$ acetic acid at ambient temperature at $10 \mathrm{~mA} / \mathrm{gel}$.

Because of differences in separation distances, the relative electrophoretic mobilities of bands were calculated from densitometric tracings made with a Canalco model D microdensitometer (Canal Industrial Corp., Rockville, Maryland, U.S.A.). Relative density of protein bands is shown by their relative widths, whereas enzymic activity is represented by different degrees of shading. Representative information for each genus and/or in some cases each species is presented. 


\section{RESULTS}

Tested bacterial isolates consistently gave characteristic patterns which were not influenced by culture growth phase (Fig. I). These patterns were generally characteristic for each bacterial species, and similar for different isolates within a given species. The variations observed were very small and largely quantitative except in isolate A-IO of Agrobacterium

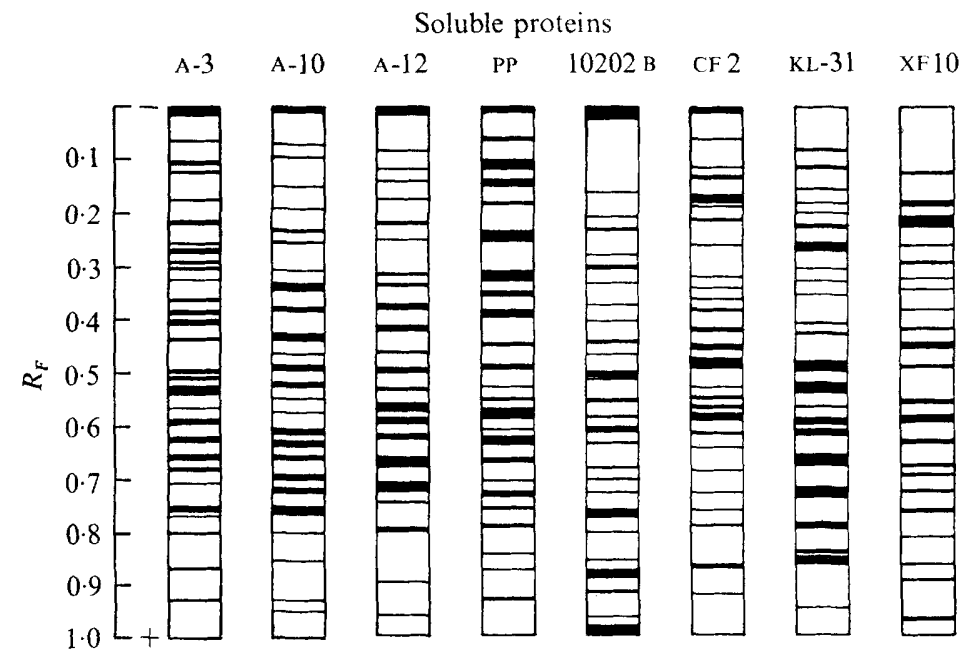

Fig. I. Zymograms of Amido black stained gels prepared from extracts of various phytopathogenic bacterial species. The code is: A-3 (Agrobacterium rhizogenes); A-10, A-12 (A. tumefaciens); PP (Pseudomonas phaseolicola); $10202 \mathrm{~B}$ (Corynebacterium michiganense); CF 2 (C. faciens); KL-3I (Erwinia carotovora); XF 10 (Xanthomonas fragariae).

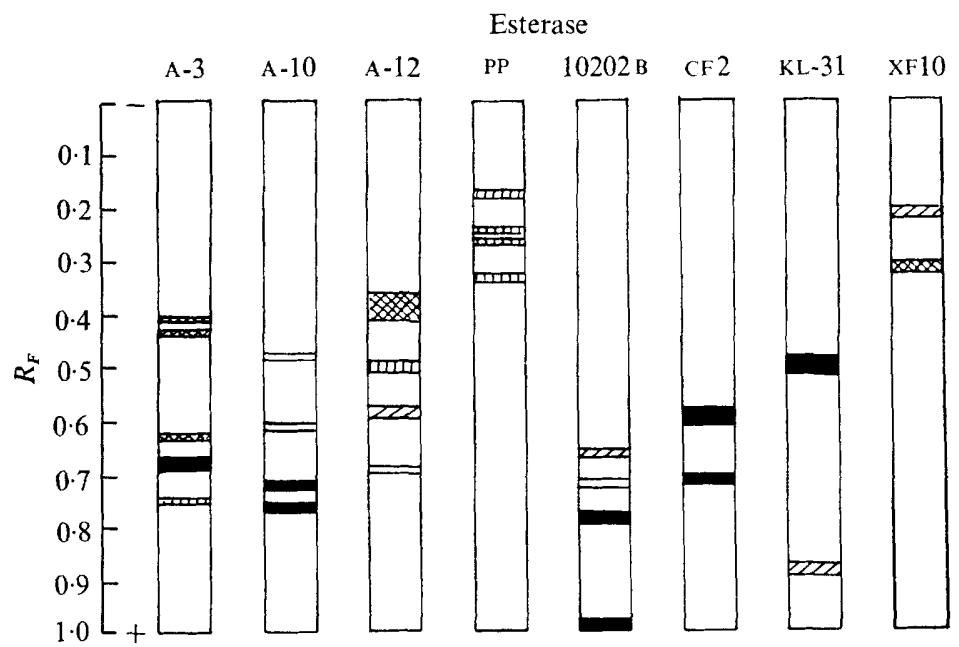

Fig. 2. Zymograms of esterase bands of gels prepared from extracts of various phytopathogenic bacterial species. The relative density of each band is represented by the different amounts of shading. The code is : A-3 (Agrobacterium rhizogenes); A-IO, A-I 2 (A.tumefaciens); PP (Pseudomonas phaseolicola); I0202 B (Corynebacterium michiganense); CF 2 (C. faciens); KL-3I (Erwinia carotovora); XF IO (Xanthomonas fragariae). 
tumefaciens which was apparently different from $\mathrm{A}-\mathrm{I} 2$ and $\mathrm{A}-\mathrm{I} 3$. All isolates of Corynebacterium michiganense had a characteristic strongly staining band close to the dye marker band. Isolates $10202 \mathrm{~A}$ and 10202 B differed, however, from the remaining isolates of the species in the presence of two very weak bands resolved at $R_{F} 0.515$ and 0.965. Minor differences were observed among isolates of Xanthomonas fragariae and were confined to the resolution of a few very weak bands in two of the four isolates. These weak bands were not always resolved in different electrophoretic runs.

Multiple forms of esterases were detected in all species tested (Fig. 2). Taxon-specific patterns were evident with slight quantitative variations depicted by the relative shading of the bands of the zymograms. Isolates of Corynebacterium michiganense had a strong band at $R_{F} 0.79$ which was comparable in intensity in all isolates. Other bands showed slight quantitative variations. Isolates A-I 2 and A-I3 of Agrobacterium tumefaciens were identical while A-IO had a different esterase pattern. Both A-I2 and A-I3 had a diffuse band at $R_{F} 0.39$ and were different from the two isolates of $A$. rhizogenes. Isolates of Pseudomonas phaseolicola had the same esterase patterns with some minor variation in the density of bands. The two isolates of Erwinia carotovora $\mathrm{K} \mathrm{I}-3 \mathrm{I}$ and $\mathrm{K} \mathrm{I}-46$ had identical activity at $R_{F} 0.50$ while they differed quantitatively in the band at 0.88 . All isolates of Xanthomonas fragariae showed almost identical quantitative patterns.

\section{DISCUSSION}

Close similarity between isolates within a species was demonstrated with all representatives of phytobacterial genera tested with the exception of isolate A-IO of Agrobacterium tumefaciens. This isolate has also been found to differ extensively from A-I2 and A-I3 in pathogenic properties. This confirms the feasibility of differentiating $A$. tumefaciens from $A$. rhizogenes by this technique (Huisingh \& Durbin, 1965, 1967). It was also possible to separate Corynebacterium michiganense from $C$. faciens by their electrophoretic protein patterns.

Esterase patterns have been found to be a useful taxonomic criterion for differentiating among different groups of bacteria (Norris, 1964; Conn \& Willox, 1965; Lund, 1965; Robinson, I966; Morichi et al. 1968). They were useful also with the strains studied, all of which had active esterases. The multiple nature of the enzyme was evident in all species. The taxon-specific patterns exhibited by isolates indicate their value as a diagnostic tool. It is obvious that an esterase band occurring at $R_{F} 0.59$ was resolved in extracts of Agrobacterium tumefaciens $\mathrm{A}-\mathrm{I} 2$ and $\mathrm{A}-\mathrm{I} 3$ and of Corynebacterium faciens $\mathrm{CF} 2$ and $\mathrm{C}-\mathrm{I} 2974$; however, they need not be structurally identical. Such identity may be tested by other chemical methods such as immunoelectrophoresis.

In view of the large number of protein bands resolved by Amido black staining, the determination of esterase patterns appears to be a faster and more useful differentiation criterion than the soluble protein patterns.

Preliminary tests for malate and glucose-6-phosphate dehydrogenases by the tetrazolium staining method (Gilbert \& Goldsberg, I966) revealed that all isolates of Corynebacterium michiganense and $C$. faciens lacked dehydrogenase activity while isolates of other genera possessed active malate and glucose-6-phosphate dehydrogenases. It has been reported that some corynebacteria are inhibited by tetrazolium salts (Lovrekovich \& Klement, 1960). Whether such inhibition is due to the effect of tetrazolium compounds on the bacterial dehydrogenases, or whether the absence of demonstrable activity is due to the unsuitability of the testing procedure is open to further studies. 
The feasibility of using polyacrylamide gel electrophoretic protein and esterase patterns for taxonomic differentiation of phytopathogenic bacteria is demonstrated by this work.

The authors wish to thank all those who contributed bacterial cultures and to acknowledge the technical assistance of Mrs Lieselotte Conniff.

This is journal series paper no. 3235 of the North Carolina Agricultural Experiment Station, Raleigh, North Carolina.

\section{REFERENCES}

Breed, R. S., Murray, E. G. \& Smith, N. R. (1957). Bergey's Manual of Determinative Bacteriology, 7th ed. Baltimore: Williams \& Wilkins Co.

Chang, L. O., SRB, A. M. \& Steward, F. C. (I962). Electrophoretic separation of the soluble proteins of Neurospora. Nature, London 193, 756-759.

ClaRE, B. G. (1963). Starch-gel electrophoresis of proteins as an aid in identifying fungi. Nature, London 200, 803-804.

Clare, B. G., Flentje, N. T. \& Atkinson, M. R. (I968). Electrophoretic patterns of oxidoreductases and other proteins as criteria in fungal taxonomy. Australian Journal of Biological Science 21, 275-295.

Clare, B. G. \& Zentmyer, G. A. (1966). Starch-gel electrophoresis of proteins from species of Phytophthora. Phytopathology 56, 1334-1 335 .

ConN, D. C. \& Willox, M. E. (I965). Analysis of multimolecular enzymes as an aid to the identification of certain rapidly growing Mycobacteria, using starch-gel electrophoresis. Journal of Applied Bacteriology 28, $165-173$.

DAvis, B. J. (1964). Disc electrophoresis II. Method and application to human serum proteins. Annals. of New York Academy of Sciences 12I, 404-427.

Durbin, R. D. (I966). Comparative gel-electrophoretic investigation of the protein patterns of Septoria species. Nature, London 210, I I 86-I 187.

El-Sharkawy, T. A. \& Huisingh, D. (1968). Identification of Xanthomonas species by acrylamide-gel disc electrophoresis of soluble bacterial proteins. Phytopathology 58, 1049 (abstr.).

Fowler, R. C., Coble, D. W., Crammer, N. C. \& Brown, T. MCP. (1963). Starch-gel electrophoresis of a fraction of certain of the pleuropneumonia-like group of organisms. Journal of Bacteriology 86, I I45II 5 I.

GiLBerT, L. I. \& GoldBerG, E. (I966). Metabolic relationships in the cockroach, Leucopheae moderae. II. Electrophoretic analysis of dehydrogenase activity in tissue extracts. Journal of Insect Physiology 12, 53-63.

GiLl, H. S. \& KHARE, M. N. (1968). Disc electrophoresis of sonic extracts of five phytopathogenic bacteria. Phytopathology 58, 105I-1052.

Gill, H. S. \& Powell, D. (1967). Differentiation of three species of Phytophthora by polyacrylamide-gel electrophoresis. Phytopathology $\mathbf{5 7}, 812$.

GotTlieb, D. \& Hepden, Pamela M. (1966). The electrophoretic movement of proteins from various Streptomyces species as a taxonomic criterion. Journal of General Microbiology 44, 95-104.

Hall, R., Zentmyer, G. A. \& ERwin, D. C. (1969). Approach to taxonomy of Phytophthora through acrylamide-gel electrophoresis of proteins. Phytopathology 59, 770-774.

HuIsingh, D. \& DURBIN, R. D. (1965). Acrylamide-gel electrophoresis of proteins from Agrobacterium species. Phytopathology 55, I062 (abstr.).

Huisingh, D. \& Durbin, R. D. (1967). Physical and physiological methods for differentiating among Agrobacterium rhizogenes, A. tumefaciens and A. radiobacter. Phytopathology 57, 922-923.

Lovrekovich, L. \& KeLment, Z. (I960). Triphenyltetrazolium chloride tolerance of phytopathogenic bacteria. Phytopathologisches Zeitschrift 39, I29-133.

Lowry, O. H., Rosebrough, N. J., Farr, A. L. \& Randall, R. J. (I95I). Protein measurement with the Folin phenol reagent. Journal of Biological Chemistry 193, 265-275.

LunD, G. (1965). A comparison by the use of gel electrophoresis of soluble protein components and esterase enzymes of some group D streptococci. Journal of General Microbiology 40, 4I 3-419.

Morichi, T., Sharpe, M. E. \& Reiter, B. (1968). Esterases and other soluble proteins of some lactic acid bacteria. Journal of General Microbiology 53, 405-414.

NoRris, J. R. (I964). The classification of Bacillus thuringiensis. Journal of Applied Bacteriology 27, 439-447. 
RAzIN, S. (I968). Mycoplasma taxonomy studied by electrophoresis of cell proteins. Journal of Bacteriology 96, 687-694.

RAZIN, S. \& RoTTEM, S. (1967). Identification of Mycoplasma and other micro-organisms by polyacrylamidegel electrophoresis of cell proteins. Journal of Bacteriology 94, I 807-1810.

RobInson, K. (1966). An examination of Corynebacterium spp. by gel electrophoresis. Journal Applied Bacteriology 29, 179-184.

RotTem, S. \& RAZIN, S. (1967). Electrophoretic patterns of membrane proteins of Mycoplasma. Journal of Bacteriology 94, 359-364.

SMITH, J. H. \& PowELl, D. (I968). A disc electrophoretic comparison of protein patterns of Erwinia amylovora with other bacteria, including associated yellow forms. Phytopathology $\mathbf{5 8}, \mathbf{9 7 2 - 9 7 5 . ~}$

StIPES, R. J. (1967). Disc electrophoresis of mycelial proteins from Ceratocystis species. Phytopathology 57, 833 (abstr.). 